\title{
Portfolio approach to project management in creation of the organization's value
}

\author{
Anna Kaczorowska ${ }^{1, *}$, Jolanta Słoniec ${ }^{2}$, and Sabina Motyka ${ }^{3}$ \\ ${ }^{1}$ University of Lodz, Faculty of Management, Department of Computer Science, Matejki 22/26 Str., 90-237 Lodz, Poland \\ ${ }^{2}$ Lublin University of Technology, Faculty of Management, Department of Enterprise Organization, Nadbystrzycka 38 Str., 20 - \\ 618 Lublin, Poland \\ ${ }^{3}$ Cracow University of Technology, Faculty of Mechanical, Department of Manufacturing Processes, M6 Institute, Jana Pawła \\ II 37 Avenue, 31-864 Cracow, Poland
}

\begin{abstract}
The composition and structure of the project portfolio were analysed and the importance of the links between particular projects and with the organization's strategy in creating of its value were emphasised in the article. As regards the information projects, profoundly analysed were the subprocesses of identification, categorization, evaluation of components, and balancing of the whole portfolio, besides the tools were proposed for them which involve the specificity of ICT undertakings, optimise the use of the organisation's resources and enable economically justified choice of projects for the portfolio. The applied research methods comprise a cross-sectional analysis of literature and analytical method. In result of the presented considerations a growing role of the portfolio approach to project management was shown along with its importance in creation of the contemporary organization's values, and the need to continue the research in the selected area was demonstrated.
\end{abstract}

\section{Introduction}

The need to implement many undertakings simultaneously appears along with complications of management problems and increasing variability of the organization's environment [1]. It causes the necessity to look at the project management from an extended perspective - not only of single projects, but also their sets - programs and project portfolios as well as the whole organization and its strategy $[2,3]$.

Project portfolios are sets of projects implemented, financed, and managed simultaneously within the same organization or its part. Portfolio components - programs and projects do not have to be interrelated and interdependent. All projects within the portfolio use the same limited resources and compete for them. Hence predominant in the Portfolio Project Management (PPM) are issues of optimised use of the organization's resources and choice of elements of the portfolio which is consistent with its strategy $[4,5,6]$.

Functioning in a multi-project environment $[7,8]$ is the most serious and at the same time relatively poorly recognized area of research, in view of the strategic management of contemporary organizations $[9,10]$.

The literature on these issues misses some research which would tackle the most difficult processes and offer instruments for such management, particularly with reference to IT projects. Therefore, the main purpose of the research was analysis of the most problematic processes and issues in IT project portfolio management and proposing for them some instruments involving the specificity of IT undertakings.

\section{Analysis of the composition and structure of the project portfolio in the context of creating organization's value}

In consequence of the concentration on direct influence of projects on achieved financial results, and hence the company's value, the point of view about project management is changing. More and more frequently the total and complex perspective, covering all projects of the organization, replaces a narrow look at single, autonomous projects.

The change in the project management viewpoint showed the need to analyse projects so as to show their interrelations, interactions, and adjustment as well as the cohesion with other projects within the organization $[5$, $11,12]$.

In the process of constructing an optimum project portfolio particularly important are economic relations between the profits generated by the projects. In this case the economic relation indicates how the profits of one project influence the profits generated by another project or the profits obtained from the present and continued non-project activity of the organization.

For economic complementarity between the projects we can distinguish 3 types of relations:

1) the projects enter the portfolio simultaneously and they should be implemented almost at the same time, 
2) the projects enter the portfolio simultaneously, and implementation of one project enables reduction of the costs of the other project without influencing its incomes or increasing the other project's incomes without increasing its costs,

3 ) projects enter the portfolio together but undertaking of one project is connected with the necessity to undertake consecutive adaptable projects (forced, otherwise referred to a "must" projects) which do not yield directly any incomes but entail investment expenditures and maintenance costs, which may decrease the profitability of the main project.

Adjustable projects (the third type of the dependence) do not maximize the organization's value. Instead, they involve the organization's resources, thereby confining the possibility to implement the projects providing commercial profits, which directly affects and determines the portfolio's composition. This may result in that the portfolio's composition will not be optimal according to the value maximization criterion, thereby the value of the portfolio-managing organization will not be maximized.

Analysing the project portfolio structure we should indicate the diversification projects and the following causes of choosing the diversification as an investment strategy:

1) limitation of a complete risk of the organization's activity resulting from its diversification (used during the crisis or worse economic situation by a narrowspecialised organizations),

2) reaching the synergy effect through connecting of several types of conducted activity and shared resources used for this purpose,

3) the necessity to "rejuvenate" the profile of the organization's activity; in this case the organization using outdated, obsolete technologies may start using new ICT (Information and Communication Technologies) in its activity.

Another important problem connected with the construction of the projects portfolio is the statistical correlation which may occur between the benefits from different projects. The statistical correlation has a time and market aspect.

The time aspect is connected with spreading of net profits (net cash flows) over time for several projects. A strong positive correlation between net cash flows generated by the projects within the portfolio occurs when in the same period most of the projects in the projects portfolio are at the same phase of life, e.g. realisation. This is connected with generating by such projects only negative net cash flows, which in a long run may be quite risky for the company's financial stability. On the contrary, a strong negative correlation occurs when projects are in different phases of life. Owing to this, some of the projects within the portfolio already generate positive financial surpluses (FCF,"+"), thereby providing the organization with the financial stability, while some are at the implementation phase, so they generate negative net cash flows (FCF,"-"), but this situation does not cause any direct risk for the organization's solvency.

The market aspect of statistical correlation becomes important when benefits from two or more projects depend on the same external market conditions (connecting the profits from two projects with the same target market) or occurrence of the same circumstances [13].

Strategic plans may impose the hierarchy of the components of resultant portfolios. Consequently, excluded from the portfolio may be those components which to the least extent contribute to accomplishment of the organization's strategic objectives. In this way the organization's strategy becomes the main factor according to which the projects are invested in. Simultaneously, the portfolio components through reports on execution and demand for changes become a source of feedback information for other programs and projects. The needs of respective components, connected with resources, are summed up and communicated at the portfolio level, which advantageously affects the organizational planning.

The value of the projects portfolio is different and specific for every type of organization. We determine the value of the portfolio differently for public organization than for non-profit organization and yet differently for stricte business organization. This results from differences in the type of activities conducted by these organizations, and consequently the objectives defined in the strategy which are to be implemented and achieved owing to the portfolio projects. In business organizations at the strategic level the information necessary for optimum management of the project portfolio is prepared, including the information about strategy-resultant business goals, expected levels of the profitability of respective projects (e.g. IRR - internal rate of return), acceptable levels of the project's financial safety margin (IRR - CC; where CC is the cost of capital), planned, expected and desirable structure of the project portfolio $[6,11,14,15,16,17]$. In case of business organization the potential criteria determining the portfolio value include among other the NPV (net present value) of single projects within the portfolio [14, 15].

\section{Key subprocesses and tools of IT projects portfolio management}

Information projects (IT projects) are defined as initiatives the important component of which is directly connected with information technology or organization. They are undertaken for business profits for achievement of which the necessary condition is the use of ICT, and a satisfactory condition - a close integration of business and technological components throughout the projects portfolio lifecycle [18].

The project portfolio is often determined for implementation of the organization's strategic plans and approved in result of the occurrence of at least one of the strategic factors, such as: market demand, strategic chance or business need, recipient's order and legal requirements.

Apart from the mentioned factors, the IT projects may be additionally evoked by the following events:

1) appearance of new technologies which depending on their maturity may be a source of developmental (research) or implementation projects, 
2) the need to reconstruct assets, resulting from aging of hardware or withdrawal of support for information systems by their suppliers,

3 ) the need to improve a specific area by the information system, e.g. the need to reduce the laboriousness of manual filling in of the holiday leave applications.

For the best possible use of the limited resources from the point of view of objectives of the organization (or its part) the project portfolio is subjected to processes defined as the project portfolio management [19].

Although the agile methodologies dedicated to IT projects offer well established, theoretically and practically, instruments for implementation and control of active portfolio projects, yet they are poorly recognized for subprocesses of identification, categorization, and evaluation of the components and balancing of the whole portfolio. Therefore in the aspect of management of "IT projects portfolio" and referring to the division of project portfolio management processes defined by Project Management Institute [19], an important issue is the analysis of the indicated subprocesses.

Correctly conducted process of information projects identification should prevent uncoordinated and uncontrolled launching of investments in the organization. In Polish enterprises practice [20] there are situations where the business need is identified but the project's information component is not recognised, which results in miscalculation of potential costs of the project and its implementation time. Alternatively, it happens sometimes that the information component is determined by the management board, while the entity responsible for IT is not involved in the process of identification, analysis and implementation, which results in the development (or choice) of systems which do not optimize the corporation architecture or its integration costs. Furthermore, when several entities construct similar information solutions (e.g. separate applications to service the financial products of the same category), they make it impossible to use the effects of the scale.

The methods recommended for use for the portfolio projects identification are:

- the method of strategic compliance in which it is assumed that the proposals of projects for the portfolio result directly from adopted strategic objectives and worked out functional strategies of the organization (development, marketing, finances, and project management); its essence is the gradual decomposition of the strategic objectives into the proposals of concrete undertakings;

- the projects distribution matrix which is to facilitate the completion of the recommended set of portfolio projects comprising all organizational levels (strategic, tactical, operational) and taking into account the division of projects into three types: innovative, improving, maintaining (continuing).

The starting point for evaluation and selection is usually categorization of the portfolio projects according to appropriate criteria. To facilitate subsequent decision- taking and optimize the level of expenditures needed for analysis of the venture we should (within the categorization subprocess) classify information projects in view of their specificity.

The projects classification criteria differ depending on the size of the portfolio management organization, e.g. the company working in one country will usually use simpler criteria $^{1}$ than international capital groups which dynamically change their organizational structure and seek an opportunity to materialize synergy.

Until recently, a relatively frequent tool categorizing information projects was the book-keeping perspective classifying IT investments according to software, hardware, network etc. The only advantage of such presentation is easiness in preparing the organization's consolidated budget, but its use in analysis of IT investments does not support changes in organization's behaviours, such as for example replacing of independent, uncoordinated setting up of projects by the capital group companies by the planned process aimed at achievement of synergy effects within the whole group.

Another useful classification is used in management of standardization of the software portfolio created and used in the organization, grouping the projects as follows: - "ready for use" information systems - constructed according to specification of demands imposed by the company, by one's own effort or with an external supplier's share;

- systems "from the shelf" - their representatives are implementations of financial and accounting systems, ERP or CRM classes, based on existing platforms and adjusted to the organization's needs through configuration rather than through construction of new modules;

- strategy and process rights - the projects oriented internally to IT management; their examples are: projects developing the computer science strategy, implementation of the process approach to serve the final users applications using the Service Desk;

- infrastructural projects referring to those components of information infrastructure which are not directly available to business users but they are necessary for efficient functioning and development of information architecture; these may be exemplified by: implementation of the so called "integration rails" (they arise to accelerate the information exchange and improve its cohesion between different systems and to facilitate and reduce the costs of the future solutions integration), construction of data centers, virtualisation of work environments causing a decrease in information service operational costs.

During categorization of IT investments, particularly useful are classifications of IT projects according to Well and Aral [21] and Ross and Beath [22], which are presented in Table 1.

The mechanism of information projects categorization based on information solutions classes (referred to by Well and Aral as information assets) allows for a certain discretionability because e.g. implementation of ERP class system may yield some transaction profits (by

\footnotetext{
1 Such companies may, for instance, refer small or less risky projects to an abbreviated path of analysis, and only large and more risky projects - to a detailed analysis.
} 
increasing the capacity of tasks and reducing the costs if only due to optimization of the level of reserves) but at the same time information profits (due to introduced integrated solution supporting everyday work and simultaneously constituting a source of current topical information about the organization's condition). The decision about the information project qualification should be then taken referring to the main cause for which the initiative was identified. The drawback of such categorisation of information projects is susceptibility to internal organizational policy aiming at e.g. perceiving the projects as strategic or informative projects, with the aim to abbreviate the analytical path without determining the target indices and measures. The indicated disadvantages may be balanced using simultaneously other classifications of IT projects.

While singling out the classes of information projects we may determine the categories of information projects for which the cost - benefit analysis:

1 ) is desirable and possible (transaction projects for which direct profits or savings may be indicated),

2 ) is desirable but difficult and inaccurate (assessment of infrastructural projects demanding the use of real options $[5,23,24]$,

3) would be desirable but is impossible or unfounded.

The model of IT investment classifications in the dimension of objective and technological scope delineates the area for determination of the project's category, and for the whole portfolio it enables constructing of a map presenting its structure (see Table 3). Such a map is counted among the matrix methods of analysis and visualisation of the portfolio which enable positioning of the currently implemented projects and determine the needs to create and develop new project initiatives. In professional literature such tools are usually called „bubble charts” because they enable a graphic presentation of projects in the portfolio with reference to two parameters. Thus the technological scope is defined in two categories:

1) lower layers of IT architecture, co-shared by many business applications, e.g. the network layer,

2) business solution supporting business processes, dedicated to satisfy the defined business need.

Practical use of the presented model imposes the need to qualify the project only to one class of IT investments.

The greatest asset in categorisation of IT projects proposed by Well and Aral [21] and Ross and Beath [22] is the support in the communication between managers from business entities and IT, which facilitates the discussion about allocation of means, profits and effects expected from the use of IT without going into technological details.

While analysing the categorisation subprocess we should pay attention to the micro-project category. This is a project below a certain value, which does not require a complete process of analysis and approval. To keep it under control the projects of this type should be registered and reported in an aggregated way (listing the quantity of micro-projects and the total value) as the portfolio component. This will allow to reduce the number of small projects, prevent including in the portfolio the large projects as several smaller projects, and will enable identification of those projects whose consolidation could increase profits or savings, for example a larger scale of shopping.

Table 1. Classification of information projects acc. to authors (own work based on [18, 21, 22, 24]).

Classification of information assets acc. to $P$. Well and $S$. Aral

- strategic - resulting from the need to maintain or gain the competitive advantage

- informative - improving the quality of available information

- transactional - improving operational processes through reduction of costs and increase in output

- infrastructural - improve infrastructure which will be useful for other projects in the future, e.g. integration projects which reduce IT costs

IT investment framework according to J. Ross and C. Beath

- experiments - innovative projects encumbered with a high risk

- transformation - projects undertaken when the key elements of infrastructure confine the possibility of further development; the management board covers the costs and usually is the owner of this class of investments, which may comprise the entire organization ${ }^{2}$; it is encumbered with a high risk and profits are difficult to quantify; calculations of the future value require the use of actual options techniques, decision trees, scenario analysis, and sensitivity analysis

- renovation/maintenance - investments in infrastructure aimed at maintaining of its functionality or

sustaining/improving its cost-effectiveness; financing according to cost-effectiveness analysis

- process improvement -projects which are investments in business processes, resulting in changes of a relatively low scale and financial effects visible in a short time after the completion of investments; financing based on costeffectiveness analysis

We can and should apply more than one tool to categorize information projects. This enables compensating for possible weaknesses of a single method and a better, more complex, comprehension of the investment portfolio and consequently the changes introduced to it. Appropriate tools of categorisation should always allow to control the processes of choice and creation of IT solutions.

The key issue in the IT projects evaluation process is the development of a set of criteria of the portfolio components evaluation. Such evaluation criteria usually comprise: profits, costs, risk, adjustment to business strategy.

Evaluation tools include experts evaluations and scoring models. The most frequent practice is their combination, i.e. subjecting the project to experts evaluation to be followed by application of a scoring model.

${ }^{2}$ For example, implementation of a new centralized banking system or the project transforming the whole company to achieve the competitive advantage. 
Popularity of the approach combining the experts evaluations with various types of scoring models or control lists results from the fact that overt identification of the factors within the scoring model increases the comparability, repetitiveness, transparency and objectivity of evaluations.

The earlier analysed categorization process may cause the use of different sets of criteria for different classes of projects. However, within one category the same criteria and rules should be applied. Examples of the criteria used for IT projects are e.g. adjustment to IT architecture or impact on business processes.

As regards IT projects, attention should be paid to the financial criterion - due to different tools which should be used during evaluation. The financial criterion should be based on analysis of obtained profits and incurred costs in connection with implementation of the IT project, using the measures 6 and tools applied for other categories of projects implemented in the organization.

Two analyses have to be carried out to use the financial measures: profit and expressing it in the form of a model of incomes (or savings), costs of construction and application of the solution.

Organizations from the ICT sector in Poland carry out analyses of costs based on the TCO (Total Cost of Ownership) approach. A reliable analysis of incomes for the IT project is not possible without involving of the entity for which a given solution will be created. The starting point for such analysis is identification of business profits which the entity plans to achieve through implementation of the project $[20,25]$.

Some classes of IT assets should be evaluated as a coshared infrastructure for the present and future investments, such as e.g. investment in a safe and efficient network infrastructure. A complete evaluation of such projects may demand the use of advanced methods of analysis (e.g. real options) which would take into account not only the infrastructural project but also all other projects which would derive profits from the new infrastructure. The portfolio managers may alternatively use a simpler approach to evaluation of the financial criterion for infrastructural projects (classification according to Weill and Aral) which does not carry out any quantitative analysis of profits obtained due to accomplishment of the initiative. This allows to avoid investing significant resources in the analysis and allows to use the openly defined class of infrastructural projects without incomes. It also allows to keep control of the project portfolio e.g. through monitoring of all infrastructural projects in the portfolio and the level of return from the portfolio as a whole.

Balancing of the portfolio supports the organisation's ability to allocate the resources according to its strategic developmental trends. Within this subprocess, we aim at maximisation of value for the organisation created by the portfolio's components within the accepted level of risk. The tool recommended for balancing of the IT projects portfolio is the method of multicriterial decisive analysis, using a set of criteria worked out by T. Grzeszczyk [26]. The skeleton of this set is formed by universal criteria, such as: the project's efficiency, effectiveness, sustainability, positive influence on the organization, relevance and utility. As supplements to universal criteria, additional detailed criteria, including technological criteria, are suggested.

\section{Conclusions}

The project portfolio management (PPM), as a sign of strategic orientation in project management, comprising comprehensive planning and allocation of resources to many projects, development and exchange of knowledge among the projects, creating the conditions for generating of innovation, seems to be a justified proposal to cope with the multi-project phenomenon.

Having the project portfolio which involves profitable undertakings and is adjusted to the organization's situation and aims is unquestionably advantageous for it. Furthermore, apart from the profitability criterion, similarly important is the choice of projects to the portfolio in view of the phase in their lifecycle, and, consequently, the demand for resources and generated incomes.

Development - among the project teams - of complex but clearly communicated relations based on cooperation, non-destructive competition or coopetition creates values for the whole organization. For example, owing to the construction of relations based on coopetition, in certain areas the project teams cooperate (implementation, use and development of shared methodologies, standards, and tools of project management, which facilitates communication and increases the efficacy of applied instruments, training courses etc.) and in other areas they compete (acquisition of resources, prestige etc.).

Ensuring of a uniform information support not only reduces the total costs of computerization but also accelerates the PPM implementation process, facilitates exchange of knowledge and experience, and increases the functionality of applied standardized tools. Many information systems supporting the project portfolio management are available on the market [27].

Although PPM is already well-founded theoretically, there are few cases of its practical applications, and its implementation in a specific organization usually arouses many doubts [28]. The doubts refer first of all to the time limits, details, and formalization level of the project management strategy and its location in relation to the superior strategy (general strategy of the organization) and other functional strategies.

Recommended instruments assigned to IT project portfolio management subprocesses are quantitative (category of micro-project; methods of financial evaluation of projects profitability, such as NPV, IRR, IRR - CC, and those based on measures of values for stakeholders, e.g. SVA - Shareholder Value Added, EVA - Economic Value Added, TCO; ROV - Real Option Valuation; scoring models), qualitative (strategic compliance method; project distribution matrix; information assets classes model; experts methods) or mixed (combining experts evaluations with various types of scoring models or control lists; model of information investments classification in the dimension of the aim and technological scope; method of multicriterial decisive analysis). 
Recommended tools for IT project portfolio management create an open set which may be extended individually, according to the needs of a concrete organization.

Assignment of indicated instruments to subprocesses of identification, categorization, evaluation and balancing informs about their highest usefulness for such solution of problems with the IT project portfolio management which would contribute to creation and development of the organization's value.

In the light of the presented conclusions, an interdisciplinary study is planned on the development of existing and searching for new tools for IT project portfolio management, which will also evaluate their usefulness.

\section{References}

1. J. Sheffield, S. Sankaran, T. Haslett, System Thinking: Taming Complexity in Project Management (ON THE HORIZON, Emerald Group Publishing Limited,_http://hdl.handle.net/10453/225 64)

2. S. Moore, Strategic Project Management. Enabling a Productive Organization (Wiley \& Sons, New Jersey, 2010)

3. P. Roberts, Strategic Project Management. Creating the Conditions for Success (Kogan Page, London, 2012)

4. M. Trocki, Nowoczesne zarzadzanie projektami (Polskie Wydawnictwo Ekonomiczne, Warszawa, 2012, 387-395)

5. W. Rogowski, Ocena projektów - koncepcje i metody (Oficyna Wydawnicza Szkoły Głównej Handlowej, Warszawa, 2013, 43-76)

6. P. Cabała, Zarządzanie portfelem projektów w organizacji: koncepcje i kierunki badań (Mfiles.pl, Kraków, 2018)

7. A. Kozarkiewicz, Z. N. UE w Kat., 224 (2015)

8. B. Wróbel, Zarzadzanie portfelem projektów jako sposób zarządzania $w$ organizacji zorientowanej projektowo

(http://www.profuturo.agh.edu.pl/pliki/Pliki III KK MU/Zbiory_referatow/527-534_NE_Wrobel.pdf)

9. S. Gregorczyk, K. Ogonek, Strategiczne zarzadzanie projektami (Bizarre, Warszawa, 2009, 15-34)

10. A. Kaczorowska, J. Słoniec, S. Motyka, Ek. i Org. Przedsięb., 12, 21-31 (2017)

11. H.A. Levine, Project Portfolio Management: A Practical Guide to Selecting Projects, Managing Portfolios, and Maximizing Benefits (John Willey \& Sons, 2005)

12. S. Collyer, C. Warren, Int. J. of PM, 27, 355-364 (2009)
13. D. Zarzecki, Zarzadzanie finansami firm - teoria $i$ praktyka (Wydawnictwo Akademii Ekonomicznej im. Oskara Langego we Wrocławiu, Wrocław, 2008, 626)

14. W. Rogowski, Rachunek efektywności inwestycji. Wyzwania teorii $i$ potrzeby praktyki (Oficyna a Wolters Kluwer business, Kraków, 2013, 146-147, 295)

15. A. Kaczorowska, J. Słoniec, S. Motyka, Comprehensive Methods of Evaluation and Project Efficiency Account, (Proceedings of the 2016 Federated Conference on Computer Science and Information Systems FedCSIS, Gdańsk, 2016, 1159 1168)

16. P.S Kodukula, Organizational Project Portfolio Management: A Practitioner's Guide (J. Ross Publishing, 2014)

17. G. Kendall, S. Rollins, Advanced Project Portfolio Management and the PMO: Multiplying ROI at Warp Speed 34465th Edition (J. Ross Publishing, 2003)

18. S. Bochnak, Strategiczne zarzadzanie projektami (Bizarre, Warszawa, 2009, 157-175)

19. Project Management Institute, Project Portfolio Management. A View from the Management Trenches (John Wiley \& Sons, Inc., Hoboken, 2009)

20. S. Bochnak, Między biznesem a technologia. Praktyki zarzadzania informatyka $w$ Polsce (Deloitte Polska, 2008, https://docplayer.pl/2235913 -Miedzy-technologia-a-biznesem-praktykizarzadzania-informatyka-w-polsce.html)

21. P. Well, S. Aral, MIT Sloan Man. Rev., 2, 47 (2006)

22. J. Ross, C.M. Beath, MIT Sloan Man. Rev., 2, 43 (2002)

23. C. Gliedman, Valuing IT Flexibility (Forester Research, 2004)

24. R.M. Bayney, R. Chakravarti, Enterprise Project Portfolio Management. Building Competencies for $R \& D$ and IT Investment Success (J. Ross Publishing, 2012, 53-105)

25. K. Jasińska, T. Szapiro, Zarzadzanie procesami realizacji projektów $w$ sektorze ICT (PWN, Warszawa, 2014, 101-150)

26. T. Grzeszczyk, Granice strukturalnej złożoności organizacji (Oficyna Wydawnicza Szkoły Głównej Handlowej, Warszawa, 2014, 255-261)

27. A. Kaczorowska, J. Słoniec, S. Motyka, IT solutions supporting the project management processes - the choice of the proper software, (ITM Web of Conferences, Lublin, 15, 2017)

28. J. Stawicki, Praktyka wdrożeń systemów zarządzania portfelem projektów (IPMA Polska, Poznań, https://jsproject.pl/blog/portfel-i-pmo/357-portfelprojektow) 